\title{
EWOLUCJA KONSTRUKCJI UBEZPIECZENIA POWAŻNYCH ZACHOROWAŃ - DOŚWIADCZENIA RYNKÓW ZAGRANICZNYCH
}

\section{WPROWADZENIE}

Poważne zachorowanie to termin niemedyczny. Niemniej jednak dla przeciętnego odbiorcy niesie on za sobą ładunek informacyjny, a szczególnie emocjonalny, wskazujący na ciężar gatunkowy zdiagnozowanej u kogoś choroby. Poważne zachorowanie kojarzy się zwykle ze stanem krytycznym, tzn. zagrażającym życiu osoby nim dotkniętej. Nie dziwi zatem, że termin ten przyjął się i upowszechnił w obrocie ubezpieczeniowym jako nazwa dla ubezpieczeń gwarantujących odpowiedzialność ubezpieczyciela w związku ze zdiagnozowaniem określonych jednostek chorobowych, uznawanych powszechnie za poważne czy tė̇ „ciężkie”.

Według raportu Międzynarodowej Organizacji Zdrowia w 2012 r. na nowotwór zachorowało 14 mln osób na świecie. Przewiduje się, że w kolejnych dwóch dekadach nowe zachorowania wzrosna do 22 mln przypadków rocznie $^{1}$. W Unii Europejskiej (UE-28) najczęstszymi przyczynami zgonów sa - obok chorób niedokrwiennych serca - także nowotwory. Według najnowszych danych w 2013 r. choroby niedokrwienne serca były przyczyną 132 zgonów na 100000 mieszkańców w UE-28, natomiast współczynnik umieralności na choroby nowotworowe wyniósł średnio 265 zgonów na 100000 mieszkańców ${ }^{2}$.

Geneza ubezpieczenia poważnych zachorowań wiąże się właśnie z zapadalnością na choroby układu krążenia oraz nowotwory, jak również z potencjalnymi skutkami finansowymi dla gospodarstwa domowego wywoływanymi przez zachorowanie któregoś z członków rodziny. Przykładowo w USA wystapienie choroby o wysokim koszcie leczenia jest przyczyną ok. 50\% bankructw ogłaszanych przez gospodarstwa domowe ${ }^{3}$. Nawet wówczas gdy członkowie takich rodzin posiadają ubezpieczenie kosztów leczenia, to umo-

${ }^{1}$ World Health Organization, Global battle against cancer won't be won with treatment alone, International Agency for Research on Cancer News Release, 3 February 2014, https://med.unsw. edu.au/sites/default/files/_local_upload/others/World-Cancer-Report-2014-Press-Release.pdf [dostęp: 15.01.2017].

${ }^{2}$ Eurostat, Dane statystyczne dotyczace przyczyn zgonu, http://ec.europa.eu/eurostat/statistics-explained/index.php/Causes_of_death_statistics/pl [dostęp: 18.11.2016].

${ }^{3}$ American Association for Critical Illness Insurance, http://www.criticalillnessinsuranceinfo.org/ [dostęp: 15.12.2016]. 
wy takie nie pokrywają wszystkich okoliczności i wydatków wywołanych zachorowaniem.

Celem niniejszego opracowania jest prezentacja ewolucji ubezpieczenia poważnych zachorowań. Ewolucja rozumiana jako proces przeobrażeń jest traktowana w pracy jako synonim rozwoju. Badanie rozwoju jest zaś zrelatywizowane do obiektu, czasu i miejsca ${ }^{4}$. Za obiekt (przedmiot) badania rozwoju przyjęto ubezpieczenie poważnego zachorowania traktowane $\mathrm{w}$ kategoriach produktu ubezpieczenia. Dodatkowo w badaniu skoncentrowano się zasadniczo na jednym aspekcie badania rozwoju, tj. na zmianach w obrębie elementów składowych produktu ubezpieczeniowego. Konstrukcja produktu analizowana jest na podstawie zakresu ubezpieczenia ocenianego w połączeniu z ograniczeniami odpowiedzialności ubezpieczyciela oraz świadczeniami dodatkowymi, które pojawiły się w efekcie działań konkurencyjnych jako elementy uatrakcyjniajace zakres ochrony ubezpieczeniowej historycznie uznawany za standardowy.

Jak sugeruje tytuł artykułu, przedmiotem badań są doświadczenia rynków zagranicznych. Ubezpieczenie poważnych zachorowań, co może zaskakiwać, wywodzi się nie z USA, ale z RPA. Następnie rozpowszechniło się na rynku brytyjskim (1986), australijskim (1987), amerykańskim (1988) i rynkach wschodniej Azji (1988) ${ }^{5}$. Choć doniesienia prasowe wskazuja, że ubezpieczenie poważnych zachorowań jest obecnie sprzedawane w ponad 50 krajach świata ${ }^{6}$, to zakres terytorialny prowadzonej analizy odnosi się przede wszystkim do tych „pierwotnych” rynków, uznawanych za ważne dla rozwoju przedmiotowego ubezpieczenia. Wskazane w pracy kierunki rozwoju produktu stanowia uogólnienie dominujących tendencji. Tym samym analiza przebiegu procesów ewolucyjnych ma poszczególnych rynkach zagranicznych mogłaby prowadzić do nieco odmiennych szczegółowych wniosków.

W odniesieniu do zakresu czasowego analizy za punkt wyjścia przyjęto moment kreacji pierwszego na świecie ubezpieczenia poważnych zachorowań. Prezentowane wyniki postępowania badawczego ukazują zatem przede wszystkim historyczny, a nie prospektywny, rozwój obranego obiektu.

Badania rozwoju ubezpieczenia poważnych zachorowań dokonano przez krytyczna analizę zagranicznej literatury przedmiotu, w tym publikacji w periodykach naukowych, materiałach konferencyjnych oraz piśmiennictwie popularnonaukowym wydawanym przez reasekuratorów międzynarodowych oraz różnego rodzaju stowarzyszenia działające w i na rzecz branży ubezpieczeniowej.

\footnotetext{
${ }^{4}$ Szerzej M. Osak, O metodzie badania rozwoju prywatnych ubezpieczeń zdrowotnych, „Wiadomości Ubezpieczeniowe" 2009, nr 1, s. 115, 118-120 i powołana tam literatura.

${ }^{5}$ Munich Re, Critical Illness Insurance, München 2001, s. 5; S. König, Critical Illness Versicherung - eine internationale Übersicht, DAA-Workshop für junge Mathematiker, SCOR, Loccum 19-20 August 2011.

${ }^{6}$ National Critical Illness Insurance Buyer Study Released, March 28, 2012, PRNewswire, http://www.prnewswire.com/news-releases/national-critical-illness-insurance-buyer-study-released-144598855.html [dostęp: 15.01.2017].
} 


\section{STANDARDOWA KONSTRUKCJA UBEZPIECZENIA - ASPEKT HISTORYCZNY}

Historia ubezpieczenia poważnych zachorowań ma swój początek w RPA. Pomysłodawca tego produktu ubezpieczeniowego był chirurg - jeden z uczestników zespołu operacyjnego, który w 1967 r. przeprowadził pierwszą na świecie międzyludzką transplantację serca - Marius Barnard ${ }^{7}$. Dostrzegł on brak oferty ubezpieczeniowej, która zapewniałaby wypłatę środków finansowych już w sytuacji zdiagnozowania choroby zagrażajacej życiu ubezpieczonego, a nie dopiero w momencie śmierci na skutek takiej choroby. Szczególnym katalizatorem powstania idei ubezpieczenia poważnego zachorowania ${ }^{8}$ był dla dr. Barnarda przypadek 34-letniej kobiety, samotnie wychowującej dwoje dzieci, u której zdiagnozowano raka płuca. Po operacji nowotworu, zaledwie w przeciagu trzech tygodni, kobieta wróciła do pracy zawodowej. Niestety po około dwóch latach kobieta zmarła na skutek odnowienia choroby. Wtedy dr Barnard żałował, że zamiast wypłaty sumy ubezpieczenia dopiero w związku ze śmiercią tej kobiety, pieniądze nie mogły być jej wypłacone wcześniej, tj. gdy zdiagnozowano u niej nowotwór.

Pierwsza polisa ubezpieczenia poważnych zachorowań została wystawiona w sierpniu 1983 r. w RPA przez Crusader Life ${ }^{9}$, przy reasekuracji zapewnionej przez GeneralCologne $\mathrm{Re}^{10}$. Należy wspomnieć, że przed komercjalizacją pierwszego na świecie ubezpieczenia poważnych zachorowań obserwowano w USA, Japonii i Izraelu rozszerzanie zakresu pokrycia tradycyjnych ubezpieczeń na życie o ryzyko zachorowania na nowotwór ${ }^{11}$. Niektórzy autorzy twierdzą zaś, że pierwowzoru tego ubezpieczenia należy się doszukiwać w ubezpieczeniach obejmujacych swym zakresem występowanie choroby polio ${ }^{12}$. Takie polisy pojawiły się w USA w 1945 r., niemniej jednak w odróżnieniu od tradycyjnego ubezpieczenia poważnego zachorowania przewidywały one pokrycie kosztów leczenia tej choroby do wysokości ustalonego w umowie limitu ${ }^{13}$. Dopiero wraz z wynalezieniem szczepionki przeciwko polio większość oferty ubezpieczeniowej zaczęto uatrakcyjniać przez rozszerzanie zakresu odpowiedzialności o zachorowanie na gruźlicę czy właśnie choroby nowotworowe.

Pierwotnie ubezpieczenie to nazwano w języku angielskim dread disease insurance, co w wolnym tłumaczeniu oznacza ubezpieczenie w związku z cho-

\footnotetext{
${ }^{7}$ The Insurance Hall of Fame, http://www.insurancehalloffame.org/MariusBarnard.pdf [dostęp: 19.11.2016].

${ }^{8} \mathrm{Na}$ podstawie Standard Life and Accident Insurance Company, Critical Illness Insurance Today, http://www.larsonfinancialadvisors.com/files/57118/SLAICO_CritcalIllnessWhitePaper.pdf [dostęp: 23.01.2017].

9 The Insurance Hall of Fame, op. cit.

${ }^{10}$ GeneralCologne Re, Critical Illness Products in South Africa. An Overview, Presentation for the International Congress of Actuaries, Cancun 2002.

${ }^{11}$ A. Dinani et al., Report of the Critical Illness Healthcare Study Group, The Staple Inn Actuarial Society, 14th March 2000, s. 6.

${ }^{12}$ A. L. Mayerson, Introduction to insurance, The Macmillan Company, New York 1962, s. 400; E. Stroiński, Ubezpieczenia na życie: teoria i praktyka, Poltext, Warszawa 2003, s. 267.

${ }^{13}$ E. Stroiński, op. cit., s. 263.
} 
robami „budzącymi postrach”. Ze względów psychologicznych i marketingowych ubezpieczyciele odeszli od oryginalnej nazwy na rzecz critical illness insurance (CI). W praktyce rynków zagranicznych ubezpieczenie to bywa także nazywane crisis cover, trauma cover, recovery cover (ubezpieczenie ,zdrowienia") lub living benefit ('świadczenie w związku z życiem) ${ }^{14}$. Na polskim rynku przyjęła się nazwa „ubezpieczenie poważnych zachorowań” lub zamiennie „ubezpieczenie na wypadek ciężkich chorób”.

Standardowa konstrukcja produktu opiera się na katalogu zdefiniowanych zdarzeń. Pierwsze ubezpieczenie w RPA gwarantowało świadczenie na okoliczność nowotworu złośliwego, zawału serca, udaru mózgu bądź konieczności przeprowadzenia operacji pomostowania aortalno-wieńcowego (by-pass) ${ }^{15}$. Z kolei pierwotny katalog zdarzeń w Wielkiej Brytanii, oprócz czterech wyżej wymienionych zdarzen, obejmował dodatkowo niewydolność nerek oraz transplantację głównych narząóow ${ }^{16}$. Enumeratywnie wyliczone zdarzenia objęte gwarancja świadczenia dotyczą nie tylko jednostek chorobowych, ale także procedur chirurgicznych ${ }^{17}$, a obecnie również różnego rodzaju niepełnosprawności. Tym samym nazwa ubezpieczenia od samego początku nie była precyzyjna. Nieadekwatność nazwy ubezpieczenia do zakresu gwarantowanej ochrony budzi zastrzeżenia doktryny, szczególnie w kontekście włączania do definicji wypadku ubezpieczenia metod leczenia. Jak się bowiem wskazuje, wybór metody leczenia jest uwarunkowany decyzją lekarza prowadzącego i w jakimś zakresie obarczony subiektywizmem, przede wszystkim jednak - w obliczu rozwoju technologii medycznych - metody leczenia ulegaja zmianom w czasie trudnym do przewidzenia przy konstruowaniu długoterminowych produktów ubezpieczeniowych ${ }^{18}$. Niemniej jednak sama konstrukcja ubezpieczenia poważnych zachorowań oparta na liście chorób (zdarzeń) uprawniających do wypłaty umówionej sumy pieniężnej była łatwa do zrozumienia przez potencjalnych klientów i to właśnie dzięki prostocie konstrukcji ochrony ubezpieczeniowej produkty te zdobywały swoją popularnośśc ${ }^{19}$.

Ubezpieczenie poważnych zachorowań przewiduje wypłatę umówionej kwoty (sumy ubezpieczenia) w przypadku postawienia diagnozy lekarskiej potwierdzającej wystapienie określonego zdarzenia. Wysokość sumy ubezpieczenia jest niezależna od kosztów leczenia choroby. Ubezpieczyciel nie narzuca sposobu wydatkowania otrzymanego świadczenia ubezpieczeniowego, a zatem nie wymaga udokumentowania poniesionych kosztów. W konsekwencji uzyskane

${ }_{14}$ Munich Re, op. cit., s. 5.

15 The Insurance Hall of Fame, op. cit.

16 A. Dinani et al., op. cit., s. 8.

${ }_{17} \mathrm{~W}$ praktyce funkcjonują także odrębne ubezpieczenia na wypadek przebycia operacji chirurgicznych „działające” na podobnych zasadach jak ubezpieczenia poważnych zachorowań. W wypadku ubezpieczenia przebycia operacji, w odróżnieniu od ubezpieczenia pokrycia kosztów operacji, prawo do świadczenia ubezpieczeniowego występuje ze względu na fakt poddania się przez ubezpieczonego określonemu rodzajowi operacji, a nie ponoszenia jej kosztów.

18 M. Szczepańska, Ubezpieczenia na życie. Aspekty prawne, Wolters Kluwer, Warszawa 2008, s. 287. Przykłady wpływu postępu medycznego w kontekście definiowania chorób - zob. P. Smalley, Critical Illness Insurance: A Medical Perspective, RGA's Global Medical Newsletter, „ReFlections" 37, 2016, s. 4.

19 Por. A. Dinani et al., op. cit., s. 4. 
środki finansowe nie muszą zostać spożytkowane na leczenie. Uznanie przez zakład ubezpieczeń zajścia wypadku ubezpieczeniowego jest natomiast obwarowane koniecznością przedstawienia dokumentacji medycznej, obejmującej wyniki badań medycznych wyspecyfikowanych w ogólnych warunkach umowy, a potwierdzających wystapienie umówionej choroby, uszczerbku czy też zabiegu leczniczego. Omawiane ubezpieczenie jest przykładem tzw. ubezpieczeń nieodszkodowawczych/ryczałtowych w odróżnieniu od ubezpieczeń odszkodowawczych, w których wysokość świadczenia ubezpieczyciela zdeterminowana jest wysokością strat/potrzeb finansowych wywołanych na skutek zdarzenia objętego ochroną ubezpieczeniową ${ }^{20}$.

Tradycyjne ubezpieczenie poważnego zachorowania oferowane było w połaczeniu z jakimś typem ubezpieczenia na życie. Przykładowo główna siła napędową popularności polis CI na rynku brytyjskim stała się ich sprzedaż $\mathrm{w}$ powiązaniu z ubezpieczeniami na życie stanowiącymi zabezpieczenie dla kredytu hipotecznego ${ }^{21}$.

Łączenie ubezpieczenia CI z ubezpieczeniem na życiem powoduje, że z konstrukcyjnego punktu widzenia ubezpieczenie poważnych zachorowań występuje nie jako samodzielne ubezpieczenie (stand-alone policy), ale jako opcja dodatkowa (rider policy). Połączenie z ubezpieczeniem na życie może oznaczać trwałe scalenie już przez ubezpieczyciela dwóch rodzajów ryzyka, tj. śmierci i zachorowania $\mathrm{w}$ jeden produkt ubezpieczeniowy. Innym rozwiązaniem jest konstruowanie odrębnych modułów/klauzul produktowych i pozostawienie ubezpieczającemu swobody w zakresie wyboru opcji dodatkowych, które dołaczy on do produktu podstawowego, tj. ubezpieczenia na życie. Należy bowiem pamiętać, że ubezpieczenie poważnego zachorowania to tylko jedna wśród wielu możliwości rozszerzania ochrony ubezpieczeniowej na wypadek śmierci o opcje dodatkowe o charakterze ubezpieczeń zdrowotnych.

Z kolei na płaszczyźnie kształtowania świadczenia ubezpieczeniowego koegzystencja ubezpieczeń CI i ubezpieczeń na życie również przyjmuje dwie postacie. Pierwsza z nich polega na tym, że ubezpieczenie na wypadek poważnego zachorowania funkcjonuje w roli akceleratora wypłaty (całości lub części) świadczenia z ubezpieczenia na wypadek śmierci (accerelated payment) ${ }^{22}$. W takim przypadku ubezpieczenie CI de facto nie niesie ze sobą znaczacego wzrostu ryzyka techniczno-ubezpieczeniowego. Z perspektywy zarówno ubezpieczyciela, jak i ubezpieczonego taki typ konstrukcji świadczenia oznacza, że z umowy ubezpieczenia gwarantowana jest wypłata jednej umówionej kwoty, niezależnie od tego, które zdarzenie nastąpiło wcześniej: poważne zachoro-

${ }^{20} \mathrm{O}$ podziale na ubezpieczenia szkodowe i ubezpieczenia sum mówi np. Z. Szymański, Charakter prawny ubezpieczenia od nastepstw nieszczęśliwych wypadków, „Wiadomości Ubezpieczeniowe” 1965, nr 7-8, s. 31 i powołana tam literatura. W terminologii anglojęzycznej mówi się odpowiednio o ubezpieczeniach typu reimbursement product/indemnity product oraz fixed benefit product - Swiss Re, Keeping healthy in emerging markets: insurance can help, „Sigma” 2015, no. 1, s. 4. Te ostatnie bywają także, nieco mylnie, nazywane „ubezpieczeniami pieniężnymi” (ang. cash benefit) - OECD, Private Health Insurance in OECD Countries, Health Project 2004, Paris, s. 104.

21 A. Dinani et al., op. cit., s. 6-7; Munich Re, op. cit., s. 36.

22 Munich Re, op. cit., s. 7, 10-11; C. Reynolds, CI Pricing Detectives, „PartnerReviews” 2016, March. 
wanie czy śmierć ubezpieczonego. Gdy rozpoznanie choroby jest zdarzeniem poprzedzającym śmierć, następuje wypłata całej sumy ubezpieczenia lub jej części, w zależności od przyjętych warunków. Tym samym w przypadku późniejszej śmierci ubezpieczonego odpowiednio nie jest wypłacane żadne świadczenie bądź wypłata obejmuje część pełnej sumy (100\%) ubezpieczenia. Forma akceleratora jest na rynkach zagranicznych (UK, Australia) cały czas bardzo popularną formą realizacji świadczenia $\mathrm{z}$ ubezpieczenia poważnych zachorowań. W tej wersji skonstruowano także pierwsze na świecie ubezpieczenie CI. Drugi typ konstrukcji świadczenia w ubezpieczeniu CI powiązanym z ubezpieczeniem na życie polega na gwarancji odrębnego, dodatkowego świadczenia na wypadek zachorowania. Tym samym wypłata świadczenia z tytułu zdiagnozowania poważnej choroby pozostaje bez wpływu na wysokość sumy ubezpieczenia gwarantowanej na wypadek śmierci ubezpieczonego.

Na rynkach rozwiniętych od początku dominowała dystrybucja ubezpieczeń poważnych zachorowań jako opcji dodatkowych do ubezpieczeń na życie ze świadczeniem typu ,akcelerator”. Z kolei oferowanie przedmiotowych ubezpieczeń jako samodzielnych umów ubezpieczeniowych jest w piśmiennictwie branżowym oceniane w kategoriach wyjątkowości. Dominacja konstrukcji typu stand-alone obserwowana jest na rynku kanadyjskim, co spowodowane zostało wątpliwościami podatkowymi związanymi z oferowaniem przyspieszonego świadczenia z ubezpieczenia na życie ${ }^{23}$. Na rynkach azjatyckich ubezpieczenie CI jest także jednym z kluczowych produktów w ofercie ubezpieczycieli na życie, choć znaleźć można przykłady rynków, na których z powodzeniem współistnieje oferta ubezpieczycieli na życie i ubezpieczycieli majątkowych (np. Korea Płd.) ${ }^{24}$.

\section{EWOLUCJA KONSTRUKCJI UBEZPIECZENIA - DOŚWIADCZENIA WYBRANYCH RYNKÓW ZAGRANICZNYCH}

Rekonstrukcję zmian w budowie produktu ubezpieczeniowego warto byłoby poprzedzić choćby krótkim zestawieniem statystycznym obrazującym popularność analizowanego ubezpieczenia na wybranych rynkach w aspekcie wolumenu składki przypisanej brutto czy liczby osób ubezpieczonych. Kwerenda ogólnodostępnych źródeł w tym zakresie nie dała niestety satysfakcjonujących rezultatów. W odniesieniu do rocznego wolumenu składki pozyskiwanej na świecie z ubezpieczeń CI dostępne sa jedynie pewne estymacje przygotowane przez globalnego reasekuratora, a dotyczące (sic!) 2009 r. Wynika z nich, że składka roczna z ubezpieczeń poważnych zachorowań wynosi ok. 20 mld euro

${ }^{23}$ Canadian Institute of Actuaries, Critically Canadian: Canadian Critical Illness Standalone Base Incidence Tables, July 2012, s. 8.

${ }^{24}$ C. Reynolds, Growth potential of critical illness insurance in Asia, „PartnerReviews” 2015, September. 
i stanowi 1\% składki światowej z ubezpieczeń na życie, a ponad połowa z tej kwoty pozyskiwana jest na rynkach Korei Płd., Chin, Malezji i Singapuru ${ }^{25}$.

Nowsze dane dotyczą co najwyżej partykularnych rynków zagranicznych, odnosząc się do różnych charakterystyk tych rynków. Na przykład z ostatniego dostępnego badania (edycja szósta 2008-2012), prowadzonego cyklicznie od połowy lat dziewięćdziesiątych ubiegłego stulecia przez Gen Re dla rynków wschodnich (Chiny, Hong Kong, Malezja, Singapur, Korea Płd., Indonezja) i Australii wynika, że na koniec 2012 r. na badanych rynkach łacznie aktywnych było ok. 100 mln polis ${ }^{26}$. Z kolei w 2014 r. w Wielkiej Brytanii zawarto ok. 510 tys. umów indywidualnych ubezpieczenia poważnych zachorowań w formule akceleratora i 21 tys. umów samodzielnych, co generowało składkę roczną z tych umów w wysokości odpowiednio 243 oraz $9 \mathrm{mln}$ funtów ${ }^{27}$. W 2014 r. w Wielkiej Brytanii sprzedaz nowych polis typu akcelerator stanowiła ok. 75\% wartości z 2000 r., a polis samodzielnych - jedynie ok. $21 \%{ }^{28}$. Dane z rynku kanadyjskiego wskazuja, że na koniec 2014 r. ok. 1,7 mln mieszkańców posiadało ochronę na wypadek poważnego zachorowania, łącznie w formule umowy indywidualnej bądź grupowej ${ }^{29}$. Od końca lat dziewięćdziesiątych XX w. indywidualne umowy ubezpieczenia CI zyskiwały na popularności i w 2014 r. stanowiły 27\% rynku indywidualnych ubezpieczeń zdrowotnych w Kanadzie, który łącznie jest wart ok. 4 mld dolarów kanadyjskich ${ }^{30}$.

Analiza doświadczeń zagranicznych w odniesieniu do zasadniczej problematyki artykułu, tj. do identyfikacji tendencji ewolucyjnych w obszarze konstrukcji produktu ubezpieczenia poważnych zachorowań, prowadzi do wniosku, że zidentyfikowane zmiany produktowe dokonywały się na kilku płaszczyznach. Zmiany te dają się zaobserwować w odniesieniu do zakresu przedmiotowego ochrony (tj. listy chorób/zdarzeń medycznych), konstrukcji świadczenia oraz dodatkowych opcji/benefitów.

\section{Zmiany w zakresie przedmiotowym (katalogu chorób)}

Naturalnego obszaru rozwoju ubezpieczenia poważnych zachorowań można upatrywać w rozszerzaniu katalogu zdarzeń (chorób) obejmowanych ochroną ubezpieczeniowa. Aktualnie na katalog chorób składa się nierzadko co najmniej kilkadziesiąt różnych zdarzeń ${ }^{31}$. Rozszerzanie zakresu pokrycia

25 S. König et al., Critical Illness insurance international overview - what can we learn from highly developed CI markets?, Newsletter SCOR Global Life 2011, April.

${ }_{26}$ J. Xiang, W. Droste, Dread disease survey 2008-2012 - a snapshot, „Risk Insight” 2015, no. 4 , s. 6 .

${ }^{27}$ Dane Association of British Insurers za: A. Couchman, Protection Review Sales Indices, Protection Review 2015, s. 2-4, http://protectionreview.co.uk/images/uploads/Chapter_AC_Sales_ Indices_2015.pdf [dostęp: 27.01.2017].

28 Ibidem, s. 5.

${ }^{29}$ Canadian Life and Health Insurance Association, Canadian Life and Health Insurance Facts. Edition 2015, Toronto 2015, s. 15.

${ }^{30}$ Ibidem, s. 23-24.

31 Por. C. Jewson, Critical Illness Insurance: An Introduction to Pricing, RGA, 22 October 2015, s. 41. W dostępnych opracowaniach można znaleźć przykłady katalogów chorób obejmujących nawet ponad 100 zdarzeń - S. König et al., op. cit. Dla przykładu w Singapurze do 
następuje także przez obejmowanie ochroną wcześniejszych stadiów danej jednostki chorobowej.

Rozbudowywanie listy chorób rodzi wątpliwości, w jakiej mierze kolejne włączane choroby pozostają chorobami poważnymi, także w kontekście powszechności zapadalności na nie. Można odnieść wrażenie, że rozszerzanie katalogu chorób jest działaniem sztucznym. W publikacjach branżowych można zaś znaleźć opinie, że konkurencja pomiędzy ubezpieczycielami na płaszczyźnie pojemności katalogu chorób przypomina „wyścig zbrojeń” ${ }^{2}$. Ubezpieczyciele dodają kolejne choroby, aby uzyskać możliwość „licytowania” się w kampaniach reklamowych na liczbę zdarzeń, podczas gdy znaczna część z nich, z uwagi na znikome prawdopodobieństwo zachorowania, nie ma w istocie wpływu na realny zakres pokrycia dla ubezpieczonego. Dobitnie obrazuja to dane, z których wynika, że za ok. 80-90\% wszystkich roszczeń z ubezpieczenia CI odpowiadają cztery podstawowe choroby, od których ubezpieczenie to wzięło swój początek ${ }^{33}$. Stąd dla zwiększenia akceptacji klientów kompleksowego zakresu pokrycia w produktach tych rozróżnia się często dwa warianty zakresu. Jeden oparty na podstawowym katalogu świadczeń oraz drugi - na katalogu rozszerzonym ${ }^{34}$. Porównanie taryfikacji obu wariantów dostarcza klientowi informacji o niewielkiej różnicy w cenie pomiędzy zakresem podstawowym a zakresem rozbudowanym. Z badań przeprowadzonych ostatnio wśród konsumentów chińskich wynika jednak, że redukowanie liczby chorób objętych ubezpieczeniem ma negatywny wpływ na wybór produktu. Przykładowo ograniczenie zakresu pokrycia z 23 jednostek chorobowych do 3 podstawowych poważnych chorób odnotowywanych w Chinach (nowotwór, udar mózgu, zawał serca) powodowało spadek zainteresowania takim produktem o ok. 14 punktów procentowych wśród respondentów posiadających ubezpieczenie CI oraz ok. 9 punktów procentowych wśród pytanych, którzy nie mieli dotąd takiego ubezpieczenia ${ }^{35}$.

Rozbudowa katalogu świadczeń wpłynęła na pewno na wzrost skomplikowania produktu i utrudnienie porównywania oferty rynkowej. Wynika to z faktu, że katalog chorób to nie tylko enumeratywne wyliczenie jedno-

2014 r. obowiązywał, wprowadzony przez regulatora limit liczby chorób, które mogą stanowić zakres ubezpieczenia (30 jednostek) - W. Droste, P. N. Yong, Critical illness standardisation - the Asian perspective, ,Risk Insights” 2016, no. 8, s. 2.

${ }_{32}$ C. Reynolds, Roots and developing structure of critical illness insurance, „PartnerReviews” 2015, July.

${ }^{33}$ Zob. np. C. Reynolds, New-age critical illness insurance, „PartnerReviews” 2015, November; GeneralCologne Re, op. cit., s. 27-28; Canadian Institute of Actuaries, op. cit., s. 12; J. Xiang, W. Droste, op. cit., s. 8-9; C. Kottoor, Critical illness insurance product innovations/challenges, Society of Actuaries, Health Meeting, Session: New Trends in Critical Illness Insurance Markets, June 15-17, 2015, Atlanta, s. 4.

${ }^{34}$ K. Kroll, Product variety in dread disease insurance, „Risk Insights” 6(1), 2002, s. 2.

${ }^{35}$ Swiss Re, Critical Illness Insurance in China. Understanding consumer preferences, Swiss Re Centre for Global Dialogue, 2016, s. 8. Inne opcje ograniczenia zakresu pokrycia sprowadzały się do: 1) wykluczenia z ochrony tylko nowotworów, 2) oferty ubezpieczenia tylko w związku z zachorowaniem na raka, 3) oferty ubezpieczenia tylko w zakresie chorób układu krążenia. Każda z opcji była mniej preferowana w obu grupach respondentów niż produkt wzorcowy o najszerszym zakresie pokrycia. 
stek, ale nade wszystko definicje poszczególnych chorób odwołujące się do parametrów medycznych. Dodatkowo definicje poszczególnych chorób stały się dla ubezpieczycieli narzędziem ograniczania zakresu odpowiedzialności. Nie zawsze parametry (charakterystyki) medyczne wymagane przez ubezpieczyciela jako potwierdzające diagnozę jednostki chorobowej odpowiadaja najnowszym praktykom medycznym. Wobec postępu medycyny ciagłe uaktualnianie definicji stało się wyzwaniem. W odpowiedzi w niektórych krajach (np. Singapur, Wielka Brytania, Izrael, Chiny, RPA, Malezja, Kanada) wprowadzono, najczęściej poprzez stowarzyszenia ubezpieczycieli, rozwiąania standaryzujące definicje chorób w ich ofercie ${ }^{36}$. Działania takie mają przede wszystkim na celu ochronę interesów konsumentów usługi ubezpieczeniowej poprzez wzrost transparentności warunków ubezpieczenia i ułatwienie porównywalności oferty.

Działania ubezpieczycieli „na katalogu chorób” podejmowane były także w kierunku dopasowania tego katalogu do potrzeb określonej grupy odbiorców i w efekcie tworzenia produktów profilowanych. Punktem wyjścia kreowania takich produktów jest założenie o jednolitości potrzeb klientów w ramach jednego segmentu lub co najmniej dużej zbieżności tych potrzeb. W ofercie ubezpieczycieli pojawiły się ubezpieczenia poważnych zachorowań profilowane ze względu na płeć oraz ubezpieczenia poważnych zachorowań dla dzieci i młodzieży. Wśród produktów skierowanych do określonej płci zdecydowanie większą popularnością cieszą się produkty dla kobiet niż dla mężczyzn ${ }^{37}$. Z kolei produkty zorientowane na dzieci, oprócz wielu chorób obecnych w zakresie ubezpieczenia dla dorosłych, przewidują ochronę dla specyficznych chorób dziecięcych. Produkty takie sa dystrybuowane jako ubezpieczenia samodzielne bądź jako element pokrycia w ramach ubezpieczenia rodzica (jako opcja dodatkowa lub też jako stały element zakresu ubezpieczenia bez możliwości rezygnacji). Ubezpieczyciele ograniczają wiek świadczenia ochrony na podstawie warunków „dziecięcych” najczęściej do 18 roku życia, maksymalnie zaś do 25 roku życia pod warunkiem kontynuacji nauki w trybie stacjonarnym. Ograniczaniu wieku towarzyszyć może uprawnienie do konwersji ubezpieczenia „dziecięcego” na ubezpieczenie dla dorosłych, bez konieczności dokonywania oceny ryzyka. W przypadku polis rodzicielskich z dodatkowym ubezpieczeniem dla dzieci stosowane jest automatycznie włączanie do ubezpieczenia dzieci urodzonych w trakcie trwania ochrony ubezpieczeniowej ${ }^{38}$.

Niestandardowym rozwiązaniem w obszarze definiowania przedmiotowego zakresu ubezpieczenia jest dystrybucja ubezpieczenia na wypadek choroby śmiertelnej (terminal illness insurance) oraz ubezpieczenia na wypadek cięż-

\footnotetext{
${ }^{36}$ Szerzej M. Gumna, Definiowanie chorób w ubezpieczeniu na wypadek poważnego zachorowania $w$ praktyce ubezpieczycieli zagranicznych, „Wiadomości Ubezpieczeniowe” 2015, nr 2, s. 100-109; N. Gatzert, A. Maegebier, Critical illness insurance: challenges and opportunities for insurers, „Risk Management and Insurance Review” 18(2), 2015, s. 264-265; W. Droste, P.N. Yong, op. cit., s. 1-4.

${ }^{37}$ K. Kroll, op. cit., s. 3.

38 S. König et al., op. cit.
} 
kiej choroby przewlekłej (chronic illness insurance) ${ }^{39}$. W pierwszym przypadku zakład ubezpieczeń rezygnuje z enumeratywnego wyliczenia jednostek chorobowych na rzecz wskazania atrybutów ogólnie pojętej choroby (tj. nieuleczalności prowadzącej do śmierci w określonym czasie). Wypłata świadczenia następuje $\mathrm{w}$ momencie zdiagnozowania choroby nieuleczalnej. Problemem o wymiarze etycznym pozostaje zaś wymóg dostarczenia przez ubezpieczonego, w celu otrzymania świadczenia, poświadczenia lekarza (lekarzy) odpowiedniej specjalności o braku rokowań na przeżycie okresu dłuższego niż wskazany w warunkach ubezpieczenia (zwykle 6 lub 12 miesięcy). W odniesieniu do ubezpieczenia choroby przewlekłej ubezpieczyciele bazują na warunkach ubezpieczenia opieki długoterminowej, gwarantując wypłatę umówionej sumy w sytuacji, gdy ubezpieczony stał się niezdolny do samodzielnego wykonywaniu dwóch, trzech z sześciu aktywności życia codziennego, takich jak: poruszanie się, kontrolowanie czynności fizjologicznych, mycie, ubieranie się, jedzenie oraz korzystanie z toalety.

Przeobrażenia produktowe w obrębie zakresu przedmiotowego ubezpieczenia doprowadziły do upowszechnienia produktu będącego - jak wspominano wcześniej - przodkiem klasycznego ubezpieczenia CI. Mowa tutaj o ubezpieczeniu na wypadek zachorowania na raka. Takie ubezpieczenia stanowia zasadniczy trzon oferty CI w Japonii i w USA ${ }^{40}$. Różnorodność zakresu pokrycia $\mathrm{w}$ takich polisach mieści się $\mathrm{w}$ ramach kontinuum od ubezpieczenia na wypadek każdego rodzaju nowotworu, poprzez ubezpieczenia na wypadek niektórych nowotworów zagrażających życiu, po ubezpieczenia na wypadek konkretnego rodzaju nowotworu (np. raka piersi) ${ }^{41}$.

\section{Zmiany w konstrukcji gwarantowanego świadczenia}

Tradycyjne ubezpieczenie CI wygasało wraz z wypłata pierwszego świadczenia, pozostawiając ubezpieczonego bez dalszego pokrycia na wypadek kolejnej poważnej choroby. Tym samym zasadnicza zmianą w obszarze gwarantowanego świadczenia była komercjalizacja ubezpieczeń zapewniajacych świadczenie za wielokrotne zachorowanie. Taka zmiana produktowa ma swoje korzenie w RPA i Izraelu ${ }^{42}$. Z uwagi na znaczny wzrost ryzyka techniczno-ubezpieczeniowego ubezpieczyciele w różny sposób ograniczają prawdopodobieństwo ponownych wypłat. Stąd gwarancja świadczenia w takich ubezpieczeniach może przyjmować postać ${ }^{43}$ :

- dostępnej łącznej sumy ubezpieczenia (100\%) i przypisania poszczególnym chorobom procentowej wartości tejże sumy. Wypłata świadczeń za kolejne zachorowania następuje do momentu wyczerpania sumy ubezpieczenia.

\footnotetext{
${ }^{39}$ Munich Re, op. cit., s. 14-15.

${ }^{40}$ C. Reynolds, Growth...; S. König et al., op. cit.

41 S. König et al., op. cit.

${ }^{42}$ K. Kroll, op. cit., s. 2; N. Gatzert, A. Maegebier, op. cit., s. 260.

${ }^{43}$ K. Kroll, op. cit., s. 2.
} 
Procentowe skalowanie wysokości świadczeń dokonuje się zwykle przez pryzmat dotkliwości chorób (w tym stadium rozwoju danej choroby) ${ }^{44}$;

- jednolitej sumy świadczenia dla każdego stanu chorobowego, której towarzyszy wprowadzenie łącznego limitu wypłaty (np. trzykrotność sumy ubezpieczenia). Odmiana tego podejścia jest proste wprowadzenie limitu liczby spełnianych roszczeń (np. maksymalnie trzy wypłaty).

$\mathrm{Z}$ uwagi na powiązania istniejące pomiędzy niektórymi zdarzeniami, skutkujace wzrostem prawdopodobieństwa zapadnięcia na jakaśś chorobę w związu z wcześniejszym rozpoznaniem innego stanu chorobowego, kreacji produktów za wielokrotne zachorowanie towarzyszy wprowadzanie dodatkowych warunków eliminujących owe współzależności. Chodzi tutaj na przykład o tworzenie matryc wyłączeń odpowiedzialności ze względu na powtarzające się lub współzależne choroby (np. tak w Australii) czy grupowanie współzależnych chorób w zbiory ${ }^{45}$ i ustalanie sumy ubezpieczenia dla danego zbioru z dodatkowym obostrzeniem prawa do jednokrotnego świadczenia w odniesieniu do chorób należących do tego samego zbioru (np. tak w Izraelu i na rynkach azjatyckich) ${ }^{46}$. Przykładowo typowe grupowanie na rynkach azjatyckich bazuje na następujących zbiorach chorób: nowotwory, choroby serca, niewydolność głównych narządów, choroby neurologiczno-mięśniowe, choroby zakaźne, urazy powstałe w następstwie nieszczęśliwego wypadku, utrata zmysłów ${ }^{47}$.

$\mathrm{Na}$ niektórych rynkach pokrycie ubezpieczeniowe w odniesieniu do wielokrotnego zachorowania uzyskuje się nie wprost, ale pośrednio przez wzbogacanie standardowej polisy (za pierwsze zachorowanie) o opcje dodatkowe działające jako surogaty ubezpieczenia za wielokrotne zachorowanie. Do opcji takich należą klauzula przywrócenia (odtworzenia) ochrony (reinstatement clause), klauzula prolongaty okresu ubezpieczenia (renewable term clause) czy klauzula „wstecznego wykupu” ubezpieczenia (buy back option). Szerzej na temat tych opcji w kolejnym fragmencie artykułu.

Niestandardowa, odbiegajacca od pierwotnej idei ubezpieczenia CI, konstrukcja gwarantowanego świadczenia przybiera niekiedy postać wypłaty okresowej (renty) ${ }^{48}$ zamiast wypłaty jednorazowej, bądź - co z perspektywy pełności pokrycia ubezpieczeniowego jest korzystne dla ubezpieczonego - postać świadczenia odszkodowawczego (a nie ryczałtowego), pokrywającego rzeczywiste koszty leczenia (w tym farmakoterapii) poważnych chorób. Specyficznym przykładem dystrybucji tych ostatnich produktów są Chiny, gdzie w 2012 r. wprowadzono pilotażowo taki typ ubezpieczenia CI jako ubezpieczenie państwowe (publiczne) ${ }^{49}$.

${ }^{44}$ Zob. np. C. Jewson, op. cit., s. 42-46; GeneralCologne Re, op. cit., s. 15-16.

${ }^{45} \mathrm{~W}$ praktyce grupowaniu chorób może jednocześnie towarzyszyć skalowanie wysokości świadczenia w zależności od dotkliwości choroby - zob. np. HannoverRe, Tired benefit critical illness cover, „Information as of January” 2015, s. 2-3.

${ }^{46}$ S. König et al., op. cit.

${ }^{47}$ K. de Braaf, Multiple critical illness benefits from market needs to product solution. AsiaPacific experience, Newsletter SCOR Global Life 2013, June; S. König, op. cit., s. 39-40.

${ }^{48}$ K. Kroll, op. cit., s. 2.

${ }^{49}$ C. Reynolds, Growth..., passim. 


\section{Rozszerzanie zasadniczego zakresu pokrycia o klauzule/ świadczenia dodatkowe}

Wśród opcji dodatkowych, które na przestrzeni lat stały się elementem konstrukcji ubezpieczenia poważnych zachorowań, wymienia się $e^{50}$ :

- klauzulę odtworzenia zakresu ochrony (reinstatement clause) - ma na celu umożliwienie kontynuacji ochrony w zakresie ryzyka poważnego zachorowania. Późniejszy zakres ubezpieczenia jest pomniejszony o chorobę, która doprowadziła do realizacji roszczenia oraz o choroby współzależne;

- klauzulę prolongaty okresu ubezpieczenia (renewable term clause) - znajduje zastosowanie w ubezpieczeniach terminowych. Ubezpieczyciel gwarantuje zawarcie kolejnej umowy ubezpieczenia (na umówiony okres) lub wydłużenie okresu ubezpieczenia pierwotnej umowy na dotychczasowych warunkach, bez przeprowadzania nowej oceny ryzyka ubezpieczeniowego;

- klauzulę „wstecznego wykupu” ubezpieczenia (buy back option) - odpowiada (i może towarzyszyć) klauzuli „odtworzenia”, przy czym stosowana jest w celu przywrócenia sumy ubezpieczenia na wypadek śmierci w przypadku ubezpieczenia typu „akcelerator wypłaty”. Decyzja ubezpieczającego o nabyciu opcji może zapaść po uzyskaniu pierwszego świadczenia, a cena za „doubezpieczenie” jest wyznaczana według „nowego” (aktualnego) wieku ubezpieczonego. Stosuje się także włączanie tej opcji do ubezpieczenia od razu przy zawarciu umowy ubezpieczenia, a składka dopłacana w momencie zadziałania klauzuli jest liczona według taryfy obowiąującej w dniu zawarcia pierwotnej umowy. Odtworzenie sumy następuje gradacyjnie (np. 25\% co roku) lub jednorazowo. W każdym przypadku podnoszenie sumy ubezpieczenia nie rozpoczyna się niezwłocznie po realizacji pierwszego roszczenia, ale dopiero pod warunkiem przeżycia przez ubezpieczonego umówionego okresu karencji (zwykle jednego roku). Choroba, która była podstawa pierwotnego roszczenia, jak i choroby z nią powiązane zostaja wykluczone z dalszego pokrycia ubezpieczeniowego;

- klauzulę rezygnacji z poboru składki (waiwer of premium), która gwarantuje, że wraz ze zdiagnozowaniem choroby nastapi zaprzestanie pobierania składki z podstawowej umowy ubezpieczenia na życie. Klauzula ta może działać na dwa sposoby. W prostszej wersji denotuje ona jedyny rodzaj gwarantowanego świadczenia ubezpieczeniowego w związku z poważnym zachorowaniem, polegający na zaprzestaniu poboru składek za ubezpieczenie na wypadek śmierci. W wersji bardziej zaawansowanej, obok zaprzestania poboru składki z ubezpieczenia na wypadek śmierci, następuje dodatkowo „normalna” wypłata umówionej sumy w związku z poważnym zachorowaniem;

- klauzulę zwrotu składki (return of premium clause), dająca prawo do zwrotu części składki w przypadku wypowiedzenia umowy lub - w ubezpieczeniach terminowych - upływu okresu ubezpieczenia. Zwrot składki warunkowany jest brakiem wystapienia poważnego zachorowania. Pomimo dość wysokich kosztów włączenia takiej klauzuli do umowy ubezpieczenia, przyczyniła się ona w ostatnich latach do wzrostu sprzedaży ubezpieczeń CI w Kanadzie ${ }^{51}$;

${ }^{50}$ K. Kroll, op. cit., s. 2-3; C. Reynolds, Roots...; S. König, op. cit., s. 32-37; K. de Braaf, op. cit.; C. Kottoor, op. cit., s. 10-12.

${ }^{51}$ Canadian Institute of Actuaries, op. cit., s. 9-10. 
- rozszerzanie zakresu świadczeń gwarantowanych o świadczenia serwisowe i dodatkowe świadczenia pieniężne poza wypłatą podstawowej sumy ubezpieczenia - chodzi tutaj o wzbogacanie ubezpieczenia np. o świadczenia typu wellness, pomagające w utrzymaniu dobrej kondycji fizycznej i psychicznej, o świadczenia o charakterze profilaktyki zdrowotnej czy też o łączenie ubezpieczenia CI z ubezpieczeniem dziennego zasiłku z tytułu pobytu w szpitalu bądź gwarancją pokrycia rzeczywistych kosztów niektórych metod leczenia.

\section{ZAKOŃCZENIE}

Ubezpieczenie poważnych zachorowań rozwijało się z sukcesem, ocenianym przez pryzmat wolumenu składki ubezpieczeniowej, praktycznie na wszystkich znaczących rynkach, na których zdecydowano się na jego wprowadzenie. Zwykle sprzedaż nabierała tempa po około pięciu-siedmiu latach od pierwszej komercjalizacji produktu na danym rynku krajowym ${ }^{52}$. Aktualnie ubezpieczenie to zajmuje ugruntowaną pozycję w ofercie ubezpieczeń osobowych.

Analiza ewolucji konstrukcji ubezpieczenia poważnych zachorowań wskazuje, że na przestrzeni ponad trzech dekad od jego powstania ubezpieczenie uległo istotnym przeobrażeniom, skutkującym przede wszystkim rozszerzeniem zakresu odpowiedzialności ubezpieczycieli z jednej strony, ale także skomplikowaniem produktu z drugiej. Po pierwszej fali zmian produktowych, skoncentrowanych głównie na ilościowym rozszerzaniu katalogu chorób objętych ochroną oraz tworzeniu produktów profilowanych dla określonych grup nabywców, ubezpieczyciele podjęli działania w kierunku tworzenia oferty nowej generacji. Ulepszanie produktu postępowało w dwóch kierunkach, tj. gwarantowaniu pokrycia ubezpieczeniowego „szybciej” - przez co rozumie się obejmowanie ochroną wcześniejszych, mniej krytycznych stadiów rozwoju choroby oraz gwarantowaniu tego pokrycia „dłużej”, co wiąże się z kontynuacją ochrony po pierwszym zachorowaniu ${ }^{53}$.

Czynnikami podtrzymujacymi potencjał rozwojowy ubezpieczenia CI sa wzrost zapadalności na choroby o charakterze cywilizacyjnym oraz rozwój technologii medycznych. Zderzenie tych dwóch czynników skutkuje z jednej strony poszerzaniem pola ubezpieczeniowego, jako że coraz więcej osób jest narażonych na zachorowanie na jakaśs poważną chorobę, z drugiej zaś - rozwój medycyny wpływa na wzrost wskaźników przeżywalności po zdiagnozowaniu poważnego zachorowania, przy czym koszty przeżycia „z chorobą” także rosną. Jednocześnie postęp w diagnostyce medycznej może powodować wzrost liczby zgłaszanych roszczeń ubezpieczeniowych. Wszystko to rodzi wyzwania dla ubezpieczycieli zarówno na poziomie kreacji produktów ubezpieczeniowych, jak i w następstwie tej kreacji - w obszarze oceny ryzyka ubezpieczeniowego i kalkulacji adekwatnej składki ubezpieczeniowej.

${ }^{52}$ K. J. Smith, Critical illness insurance - a product for many needs, „Life Insurance Selling” 87(2), 2012, s. 50.

${ }^{53}$ Por. K. de Braaf, op. cit. 
W obliczu trendów demograficznych, sprowadzających się łącznie do starzenia się społeczeństw, wyzwaniem dla ubezpieczycieli pozostaje tworzenie produktów dla osób starszych ${ }^{54}$. Oprócz wydłużania dopuszczalnego wieku wstępu do ubezpieczenia czy maksymalnego wieku świadczenia ochrony ubezpieczeniowej pożądane jest tworzenie ubezpieczeń poważnych zachorowań w połączeniu ze świadczeniami assistance dla osób starszych. Wraz ze wzrostem liczebności ubezpieczonych w wieku starszym wprowadzane zmiany produktowe będą dotyczyć także intensyfikacji wykorzystania instrumentarium ograniczania wskaźników szkodowości. Innymi słowy, wydłużanie okresu ochrony ubezpieczeniowej będzie szło $\mathrm{w}$ parze $\mathrm{z}$ degresywną konstrukcja przedmiotowego zakresu odpowiedzialności oraz wysokości gwarantowanych świadczeń ${ }^{55}$.

Wzrost przeżywalności w związu ze zdiagnozowanymi chorobami, jak również wzrost oczekiwanej długości życia, rodzi zapotrzebowanie na kontrakty długoterminowe $\mathrm{z}$ gwarancja poziomu składki. Produkty takie mogą być tworzone zgodnie $\mathrm{z}$ klauzulą niezmienności składki w całym okresie umowy lub - w wersji łagodniejszej z perspektywy ubezpieczyciela - gwarantować niezmienność składki w ograniczonym czasie (przez umówioną liczbę lat) lub w ograniczonym zakresie (np. gwarancja, że składka nie wzrośnie o więcej niż określony procent składki wyjściowej).

Poziom skomplikowania definicji o charakterze medycznym i konieczność przekładania tychże definicji chociażby na procedury underwritingu czy postępowania likwidacyjnego wymusi intensyfikację działań na rzecz „łatwiejszej” konstrukcji produktu. W tym duchu należy oceniać propozycje odchodzenia od tworzenia ubezpieczenia poważnych zachorowań zgodnie z definicjami medycznymi licznych chorób na rzecz uzależniania odpowiedzialności ubezpieczyciela od wystapienia „zdarzenia zmieniającego życie” (life-changing event) ubezpieczonego ${ }^{56}$. W tym drugim przypadku ubezpieczyciel byłby zobowiązany do wypłaty świadczenia w sytuacji, gdy ubezpieczony doświadczyłby takiego zdarzenia chorobowego, które istotnie wpływałoby na zmianę jego dotychczasowego życia, skutkując np. niezdolnością do pracy czy ograniczeniem zdolności do samodzielnej egzystencji. W efekcie przyszłość ubezpieczenia poważnego zachorowania może wiązać się z jego upodobnieniem do ubezpieczenia niezdolności do pracy czy ubezpieczenia opieki długoterminowej.

\section{dr Magdalena Osak}

Uniwersytet Ekonomiczny w Poznaniu

magdalena.osak@ue.poznan.pl

\footnotetext{
${ }^{54}$ Dostępne dane wskazuja, że w strukturze aktywnych umów ubezpieczenia CI w posiadaniu osób w wieku 60+ stanowią marginalną część (ok. 1-2\%) - T. Eppert, Critical illness - fit for the elderly?, „Risk Insights” 18(3), 2014, s. 2.

${ }^{55}$ Ibidem, s. 2-5.

${ }^{56}$ C. Reynolds, Product innovations in critical illness, 12th Geneva Association Health and Ageing Conference „Insuring Health Care for the Elderly in Asia”, 16-17 November 2015, Singapore, s. 19-21.
} 


\section{EVOLUTION OF CRITICAL ILLNESS INSURANCE PRODUCT DESIGN ACCORDING TO THE INTERNATIONAL EXPERIENCE}

\section{Sum mary}

The first critical illness insurance was sold in South Africa in 1983. Since that time, it has become a standard insurance cover offered in many markets around the world. Over the years the critical illness insurance product has been developed and redesigned. The scientific literature which deals with critical illness insurance focuses mainly on its actuarial and underwriting aspects. Other issues like the product design and market development are discussed primarily in the industry reports that are usually prepared by the employees of international reinsurance companies. This paper presents the evolution of the critical illness cover from the product design point of view. The territorial scope of the analysis applies primarily to those international markets which have affected the development of critical illness insurance product significantly. An attempt is made to generalise the dimensions of the product development which have been identified as dominant. It means that the analysis of the evolution of the critical illness insurance conducted for each separate foreign market could result in differences in detailed findings. 
